\title{
Aplikasi Marketplace Penyewaan untuk Koperasi Menggunakan Laravel ${ }^{1}$ Tristiyanto, ${ }^{2}$ Yunda Heningtyas \& ${ }^{3}$ Hanan Risnawati
}

\author{
1,2,3 Jurusan Ilmu Komputer, Universitas Lampung, Jalan Prof. Dr. Soemantri Brojonegoro No. 1, \\ Bandar Lampung, Indonesia \\ e-mail : ${ }^{1}$ tristiyanto.1981@fmipa.unila.ac.id, ${ }^{2}$ yunda.heningtyas@ @mipa.unila.ac.id, \\ 3hanan.risnawati1062@students.unila.ac.id
}

\begin{abstract}
Cooperatives have purpose to prosper their members. Cooperatives are expected to play an active role in raising their standard of living. A cooperative has several types of business units in order to fulfill the purpose, for example rental business. Rental occurs because of short-term and urgent needs of consumers. Rental business has been promoted online but there are a lot of ordering phases done manually. Cooperative needs a rental marketplace application so cooperative can be more productive. This rental marketplace is a web based application and developed using Extreme Programming method which perceptive to user's need. Laravel framework with PHP programming language was used to build this application. The conclusion of this research is this system is able to facilitate the process of renting goods, providing accurate information about rental goods, and expanding the cooperative business sector.
\end{abstract}

Keywords: Extreme Programming; Laravel; Rental Marketplace.

\section{PENDAHULUAN}

Koperasi turut berperan dalam meningkatkan kesejahteraan ekonomi baik bagi anggotanya maupun masyarakat di sekitarnya [1]. Kegiatan usaha yang dapat dilakukan untuk memenuhi peran tersebut diantaranya penyediaan barang atau jasa dengan tawaran atau syarat yang lebih menguntungkan [2], misalnya penyewaan barang [3]. Penyewaan terjadi karena adanya kebutuhan konsumen yang sifatnya jangka pendek, mendesak, dan barang tersebut tidak selalu harus dibeli [4]. Penyewa meminjam barang dari pemilik dalam jangka waktu tertentu dengan pembayaran sejumlah uang sesuai kesepakatan pihak penyewa dan pemilik barang [5]. Objek dalam penjanjian sewa menyewa adalah barang dengan syarat tidak bertentangan dengan undang-undang, ketertiban dan kesusilaan [6]. Proses penyewaan yang dilakukan secara konvensional menyulitkan penyewa karena penyewa harus mengunjungi pemilik barang secara langsung untuk mengetahui informasi mengenai barang yang disewakan. Pemilik barang yang melakukan pencatatan transaksi penyewaan secara manual juga dihadapkan pada beberapa kendala diantaranya penentuan jadwal penyewaan menjadi sulit, lambat dalam mengakses data penyewaan, hingga memungkinkan terjadinya data hilang [4]. Pemanfaatan teknologi seperti marketplace dapat digunakan oleh koperasi untuk tujuan pemasaran sehingga efektivitas pemasaran produk dapat ditingkatkan. Marketplace merupakan pasar secara virtual berbasis internet dimana setiap usaha dapat memperkenalkan produk dan melakukan transaksi pertukaran barang atau jasa. Marketplace juga dapat dikategorikan sebagai hubungan transaksi secara langsung maupun tidak langsung sehingga marketplace dapat mempermudah suatu usaha dalam menyampaikan detail informasi mengenai produk yang mereka pasarkan [7].

Pada penelitian Pengembangan Aplikasi Portal Penyewaan Barang di Kota Malang Berbasis Web, disebutkan bahwa penyewa perlu melakukan riset untuk memilih jasa penyewaan yang tepat karena informasi yang tersedia kurang lengkap. Melalui aplikasi penyewaan barang ini, jasa penyewaan dan penyewa di Kota Malang dapat melakukan transaksi penyewaan barang secara online. Jasa penyewaan pun dapat mempromosikan barangnya secara luas dan penyewa tidak perlu mengunjungi jasa penyewaan secara langsung. Aplikasi ini dikembangkan menggunakan metode prototyping dengan bahasa pemrograman PHP7 [4]. Kelemahan dari aplikasi ini adalah aplikasi hanya berlaku di satu kota dan tidak disebutkan penggunaan framework dalam pengembangan sistem. Penggunaan framework membuat komponen pemrograman siap re-use (bisa digunakan ulang) sehingga programmer tidak harus membuat skrip yang sama untuk tugas yang sama [8]. Framework Laravel sangat membantu pengembang yang bekerja dalam satu project karena standar penulisan kode program wajib diikuti oleh setiap orang yang ada dalam tim pengembang [9]. Penggunaan framework Laravel 
selain dapat mempermudah proses perancangan, pengembangan, pemeliharaan, juga dapat memberikan keamanan dari serangan eksternal [10]. Aplikasi marketplace penyewaan untuk koperasi berbasis website bertujuan untuk mempertemukan penyewa dan jasa penyewaan sehingga transaksi penyewaan barang dapat dilakukan secara online. Keunggulan sistem ini diantaranya dapat memperluas sektor usaha koperasi, dapat digunakan oleh lebih dari satu koperasi atau toko sewa, mengelola transaksi penyewaan, membuat akun toko sewa online, serta terdapat fitur promo khusus bagi anggota koperasi yang melakukan penyewaan di koperasi miliknya.

\section{METODOLOGI PENELITIAN}

Aplikasi marketplace penyewaan untuk koperasi dikembangkan dengan menggunakan metode Extreme Programming. Extreme Programming merupakan metode pengembangan perangkat lunak yang dapat mempercepat pembangunan suatu sistem, menyederhanakan tahap-tahap pengembangan menjadi lebih adaptif, efisien, dan mengutamakan fleksibilitas terhadap perubahan yang terjadi selama pengembangan sistem [11]. Tahapan yang dilakukan pada metode Extreme Programming ditunjukkan pada Gambar 1.

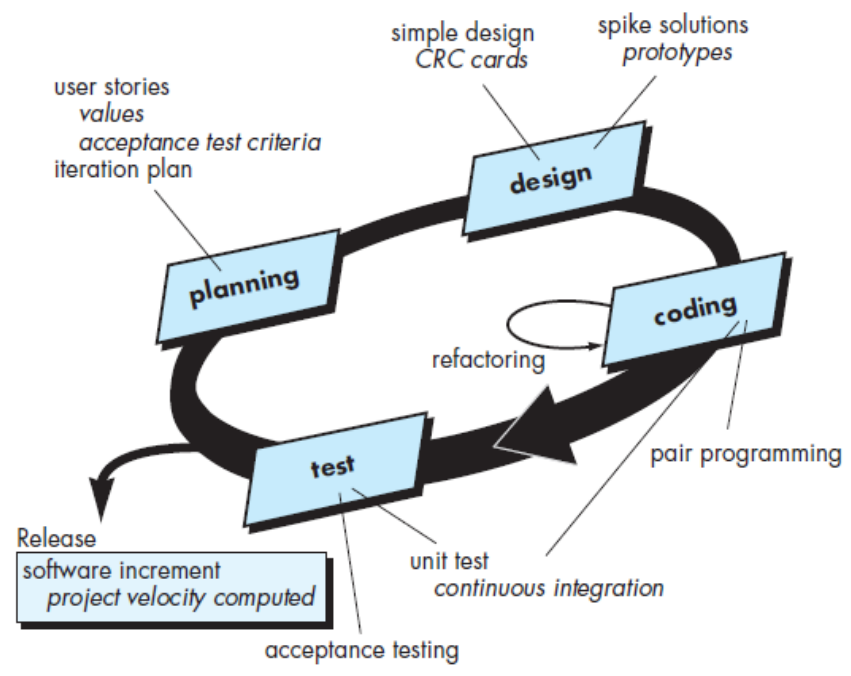

Gambar 1. Tahapan extreme programming [12]

Extreme programming memiliki empat tahapan yaitu planning, design, coding, dan testing [12]. Masingmasing tahapan dijelaskan lebih lanjut pada poin $2.1-2.4$.

\subsection{Tahap Perencanaan (Planning)}

Tahap planning dimulai dengan mengumpulkan requirement atau membuat user stories yang menggambarkan output, fitur, dan fungsionalitas yang diperlukan untuk perangkat lunak yang akan dibangun. User memberikan nilai prioritas ke stories berdasarkan nilai bisnis keseluruhan dari fitur atau fungsi [12]. User stories direpresentasikan dengan pemodelan diagram UML (Unified Modeling Language) yang terdiri dari usecase diagram, activity diagram, dan class diagram menggunakan StarUML versi 2.8.0. Usecase diagram digunakan untuk mengetahui aktor-aktor yang akan menggunakan sistem dan fungsi-fungsi apa saja yang dapat dilakukan oleh aktor tersebut [13]. Usecase diagram aplikasi marketplace penyewaan untuk koperasi memiliki 21 usecase dengan 4 user utama. Usecase diagram aplikasi marketplace penyewaan untuk koperasi ditunjukkan pada Gambar 2.

Aplikasi marketplace penyewaan untuk koperasi memiliki empat tingkatan user yaitu super administrator, administrator, penyewa, dan pengunjung. Berikut penjelasan tiap-tiap user: 
Vol 8 No. 1,2020

(C)2020 Ilmu Komputer Unila Publishing Network All Rights Reserved

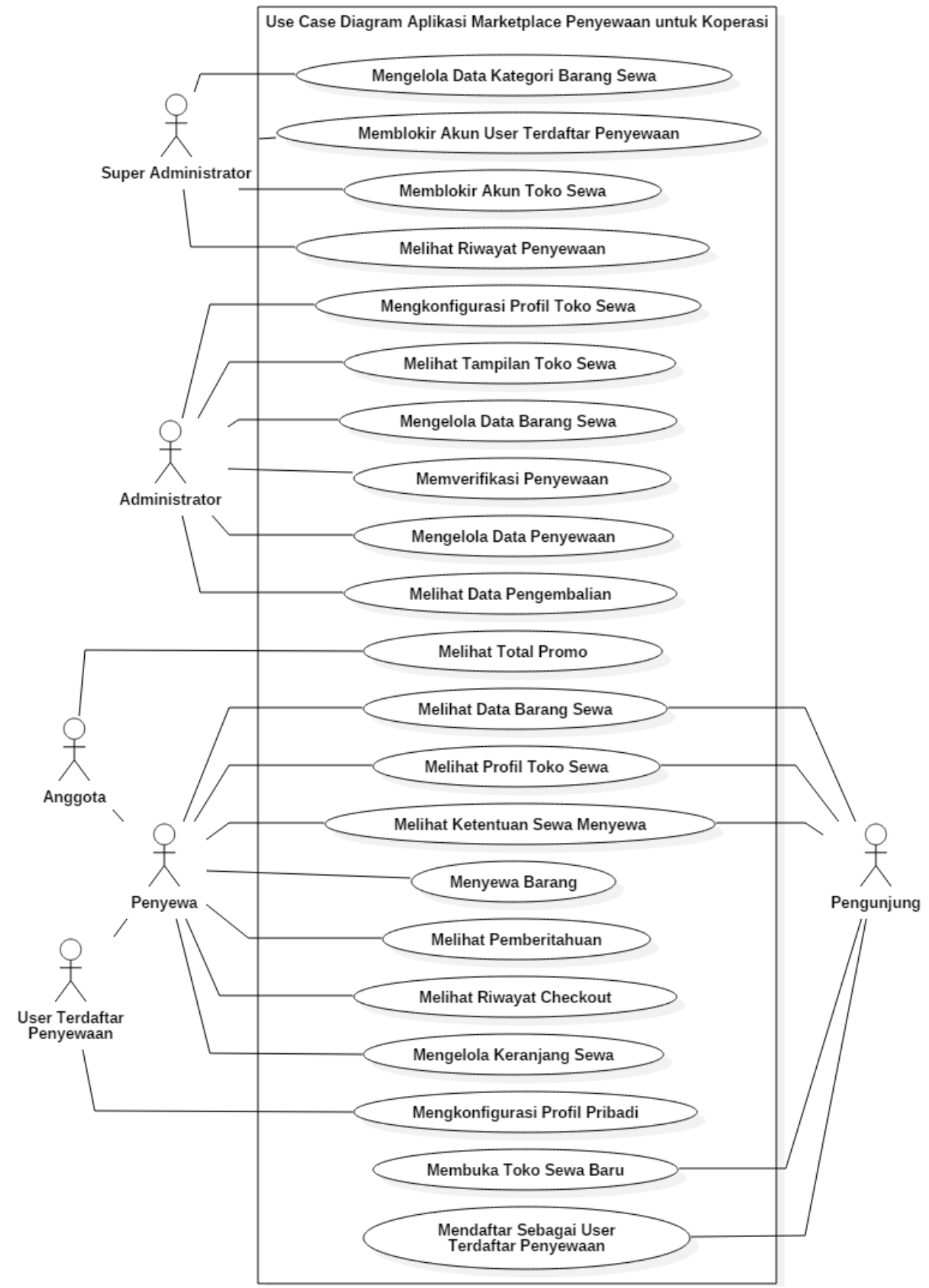

Gambar 2. Usecase diagram aplikasi marketplace penyewaan untuk koperasi

- Super administrator merupakan tingkatan user tertinggi yang bertugas sebagai pengelola aplikasi marketplace penyewaan secara keseluruhan.

- Administrator adalah orang yang bertanggung jawab secara penuh untuk mengelola suatu toko sewa.

- Penyewa terbagi menjadi dua, yaitu anggota dan user terdaftar penyewaan. Anggota adalah orang yang terdaftar di salah satu koperasi baik koperasi inti maupun koperasi mitra sedangkan user terdaftar penyewaan adalah orang yang tidak terdaftar di koperasi manapun tetapi terdaftar di aplikasi marketplace penyewaan.

- Pengunjung merupakan orang yang mengunjungi aplikasi marketplace penyewaan dan tidak terdaftar sebagai siapapun. 


\subsection{Tahap Perancangan (Design)}

Design adalah tahap kedua dari extreme programming. Design merupakan panduan implementasi berisi pembuatan sketsa antarmuka sistem yang nantinya akan dijadikan acuan saat proses coding berdasarkan user stories yang ada [12]. Design antarmuka untuk super administrator, administrator, penyewa, dan pengunjung dibuat dengan menggunakan software Balsamiq Mockups versi 3.5.14.

\subsection{Tahap Penulisan Kode Program (Coding)}

Tahap penulisan kode program adalah tahapan yang menerjemahkan bentuk diagram sistem dan design antamuka sistem yang telah dibuat ke dalam bahasa pemrograman [14]. Penulisan kode program yang dilakukan dalam pembuatan aplikasi marketplace penyewaan menggunakan bahasa pemrograman PHP dengan framework Laravel.

\subsection{Tahap Pengujian (Testing)}

Pengujian extreme programming fokus pada keseluruhan fitur sistem dan fungsionalitas yang dapat dilihat dan ditinjau oleh user yang berasal dari user stories yang telah diimplementasikan [12]. Pengujian aplikasi marketplace penyewaan menggunakan black box testing berfungsi untuk menguji perangkat lunak dari segi spesifikasi fungsional tanpa menguji desain dan kode program [15]. Pengujian dilakukan untuk mengetahui apakah fungsi, masukan, dan keluaran dari perangkat lunak telah sesuai dengan spesifikasi yang dibutuhkan. Metode equivalence partitioning dipilih dalam pengujian ini. Equivalence partitioning merupakan teknik black-box testing yang membagi domain masukan dari program kedalam kelas-kelas sehingga test case dapat diperoleh [12].

\section{HASIL DAN PEMBAHASAN}

Hasil dan pembahasan terdiri dari dua bagian yaitu implementasi dan pengujian. Implementasi berisi antarmuka hasil penulisan kode program dan pengujian berisi hasil pengujian aplikasi marketplace penyewaan untuk koperasi.

\subsection{Implementasi}

Implementasi hasil design dilakukan dengan penulisan kode program menggunakan framework Laravel dengan bahasa pemrograman PHP serta HTML dan CSS yang berguna untuk membangun antarmuka. Database yang digunakan adalah MySQL. Penulisan kode program pada sistem ini menggunakan Sublime Text Version 3.0 build 3126. Hasil penulisan kode program ditunjukkan pada gambar-gambar berikut:

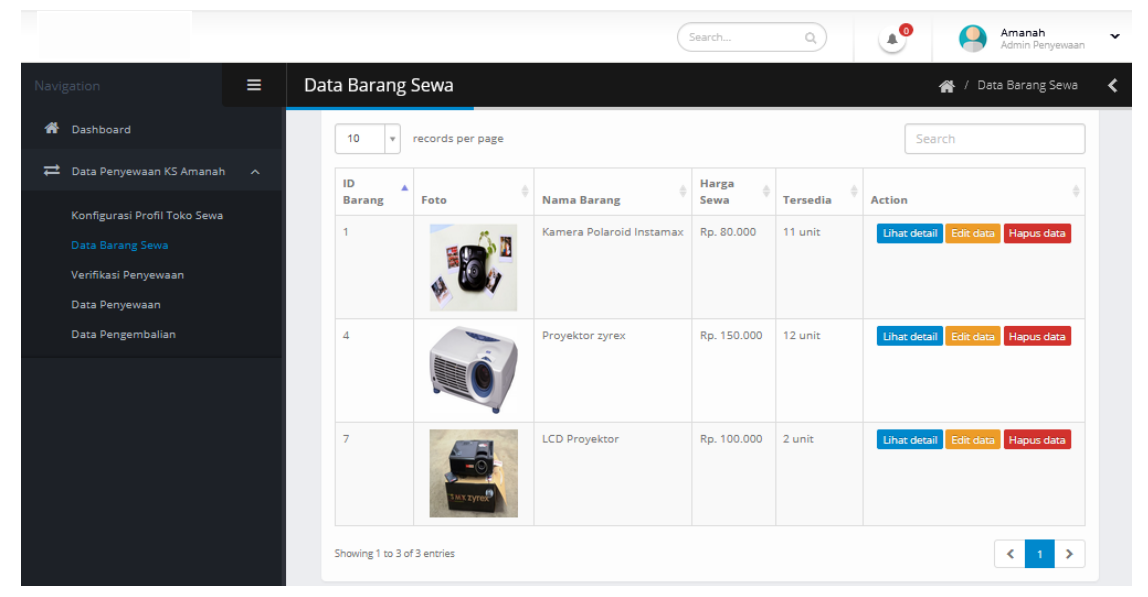

Gambar 3. Data barang sewa untuk administrator 
Gambar 3 menunjukkan antarmuka untuk mengelola data barang sewa. Tabel data barang sewa berisi barangbarang sewa yang ada di toko sewa tersebut. Administrator dapat melihat detail barang sewa, menambah, mengubah, atau menghapus data barang sewa.

Administrator dapat mengkonfigurasi profil toko sewa miliknya. Gambar 4 memiliki tiga tab yaitu profil, ubah akses, dan ubah foto.

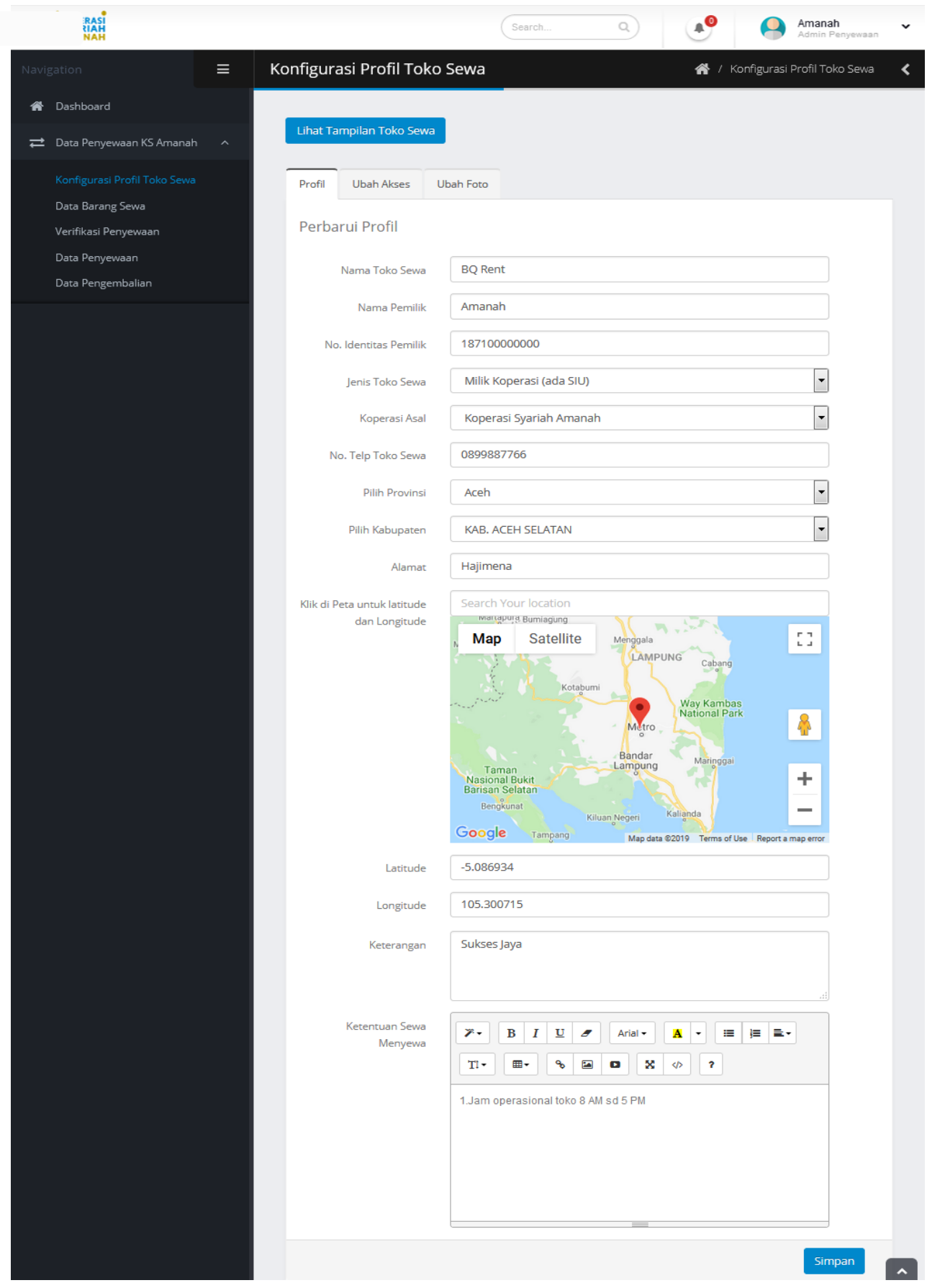

Gambar 4. Konfigurasi profil toko sewa untuk administrator 
Tab profil berisi form untuk mengubah informasi detail mengenai toko sewa. Tab ubah akses berisi form untuk mengubah e-mail atau password akun administrator penyewaan. Tab ubah foto berisi form untuk mengubah foto toko sewa, foto ktp pemilik, dan foto surat izin usaha.

Antarmuka verifikasi penyewaan ditunjukkan pada Gambar 5. Antarmuka ini berisi data permintaan penyewaan kepada toko sewa yang bersangkutan yang belum diverifikasi oleh administrator.

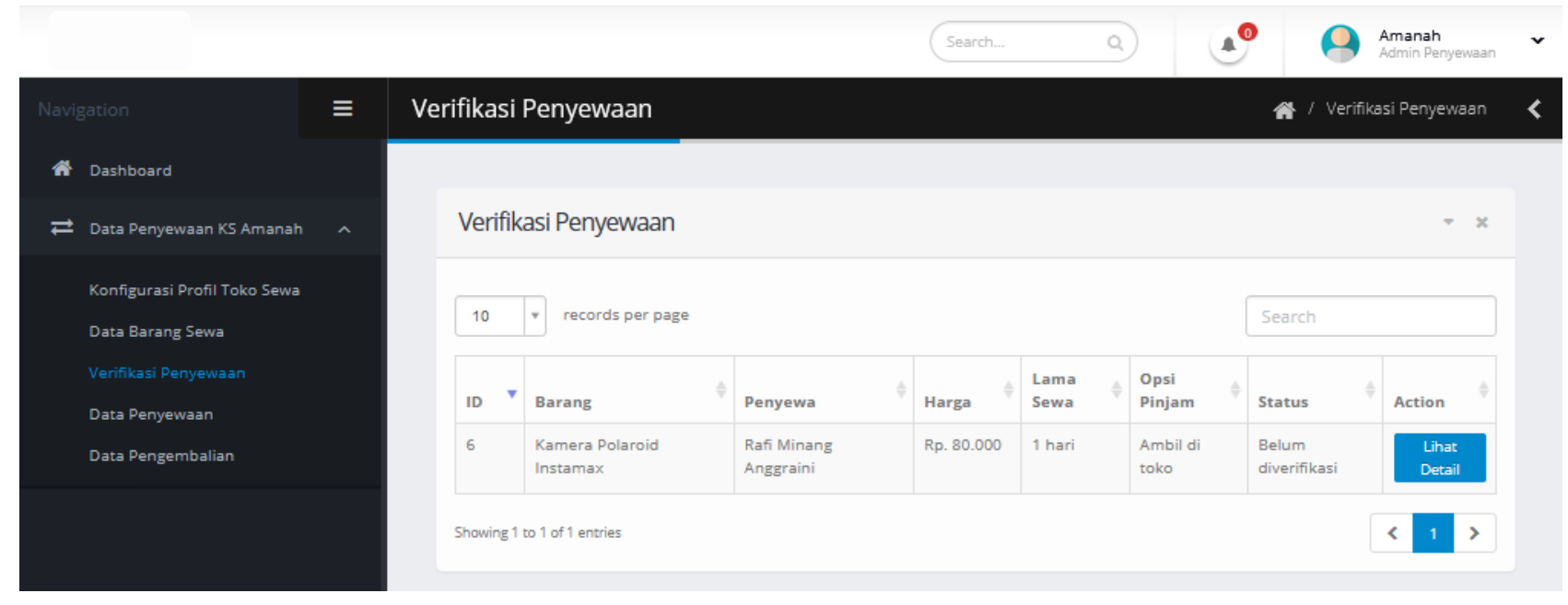

Gambar 5. Verifikasi penyewaan untuk administrator

Administrator dapat memverifikasi atau menolak permintaan penyewaan dengan mengklik tombol lihat detail. Tombol verifikasi dan tombol tolak pada halaman detail verifikasi penyewaan akan aktif setelah penyewa meng-upload bukti pembayaran. Permintaan penyewaan yang telah diverifikasi akan tampil pada halaman data penyewaan.

Gambar 6 berisi tabel yang berisi data penyewaan yang telah diverifikasi. Administrator dapat mengubah status penyewaan, mencetak receipt penyewaan, memberi peringatan pengembalian, dan input data pengembalian.

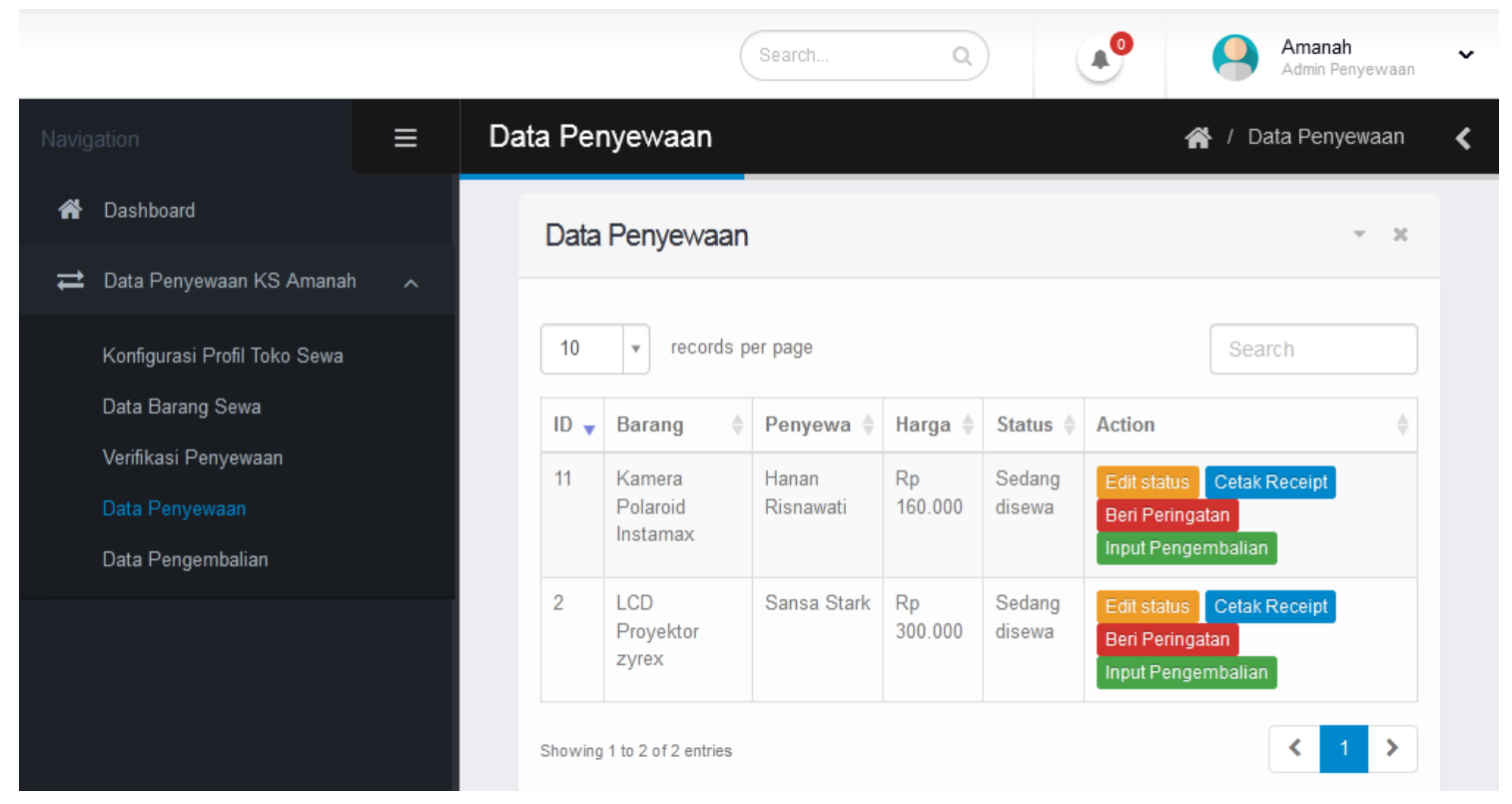

Gambar 6. Data penyewaan untuk administrator 
Tombol edit status akan mengarahkan administrator ke form edit status untuk melihat detail penyewaan tersebut sekaligus mengubah status penyewaan. Tombol cetak receipt akan menampilkan receipt dari penyewaan yang dipilih. Tombol beri peringatan berfungsi untuk memberi peringatan pengembalian barang kepada penyewa sebelum memasuki batas akhir pengembalian. Tombol input pengembalian akan mengarahkan administrator ke form input pengembalian yang berisi field tanggal pengembalian dan denda.

Administrator juga memiliki hak untuk melihat data pengembalian milik toko sewa yang dikelola olehnya. Antarmuka pada Gambar 7 berisi data pengembalian barang sewa.

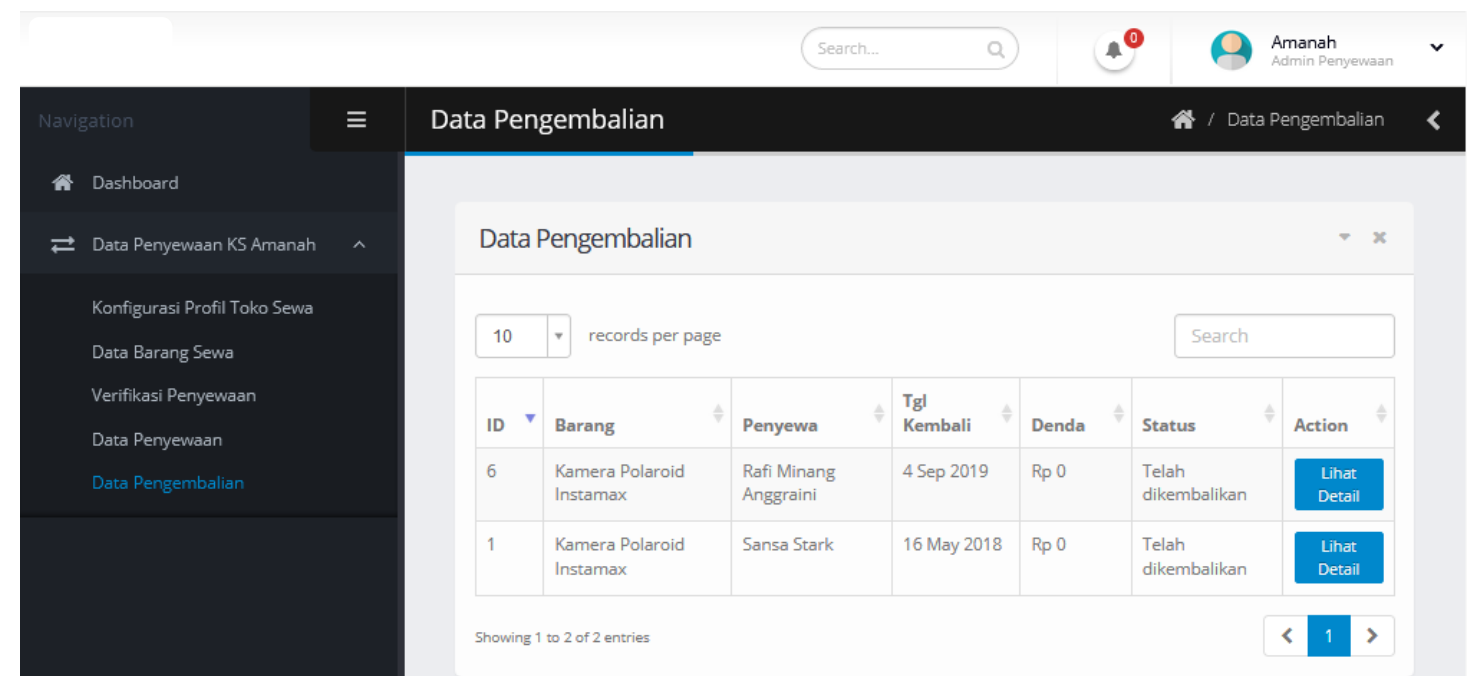

Gambar 7. Data pengembalian untuk administrator

Data pengembalian berisi data penyewaan yang telah selesai dan barang sewa telah dikembalikan. Tombol lihat detail pada Gambar 7 akan mengarahkan administrator ke pop-up yang berisi detail penyewaan berdasarkan ID penyewaan yang dipilih.

Antarmuka data barang sewa untuk pengunjung ditunjukkan pada Gambar 8. Antarmuka ini berisi foto-foto, nama barang, dan harga barang yang disewakan dari seluruh toko sewa yang terdaftar pada aplikasi marketplace penyewaan. 


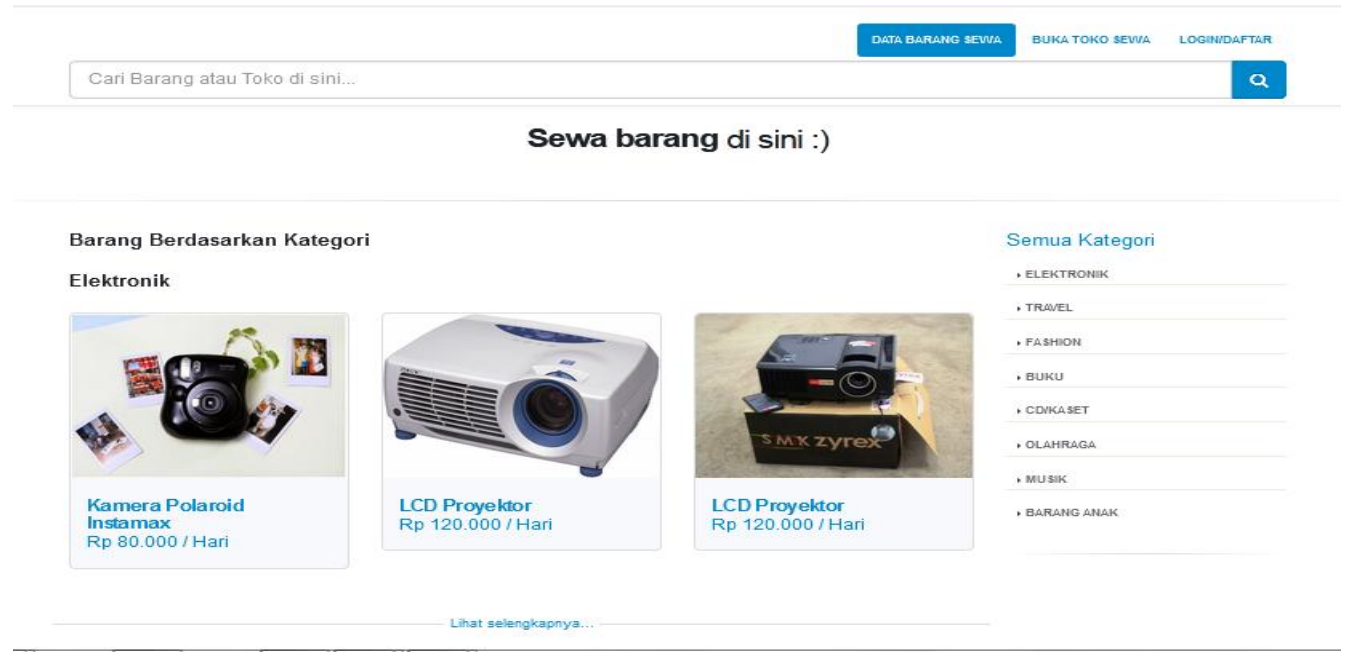

Gambar 8. Data barang sewa untuk pengunjung

Barang yang ditampilkan diurutkan berdasarkan kategori barang sewa. Side bar di sebelah kanan menampilkan kategori-kategori barang sewa yang ada pada aplikasi. Detail barang sewa dapat dilihat dengan cara mengarahkan kursor pada foto barang sewa lalu klik pada tulisan lihat detail. Pengunjung akan diarahkan ke antarmuka detail barang sewa seperti pada Gambar 9.

Gambar 9 menampilkan informasi yang lebih detail mengenai barang sewa seperti foto barang, nama barang sewa, harga sewa per hari, nama toko sewa yang berupa link, jumlah barang sewa yang tersedia pada toko tersebut, durasi maksimum peminjaman barang dalam satuan hari, kategori barang sewa, besar promo yang akan didapatkan anggota koperasi, diskon penyewaan barang per satu kali transaksi, serta deskripsi mengenai barang sewa. Pengunjung dapat mengunjungi profil toko sewa dengan mengklik link nama toko sewa. Pengunjung yang ingin menyewa barang harus membuat akun user terdaftar penyewaan atau menjadi anggota koperasi terlebih dahulu.

Data Barang sewa

BUKA TOKO SENA

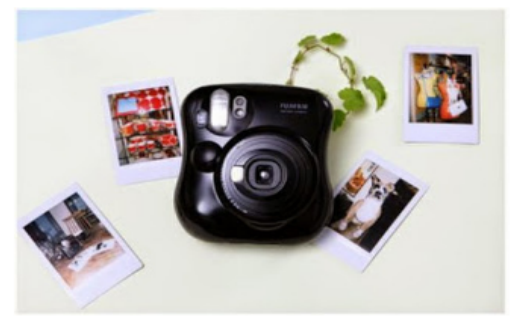

\section{Kamera Polaroid Instamax}

Rp 80.000 / Hari

* TOKO SEWA : BQ RENT

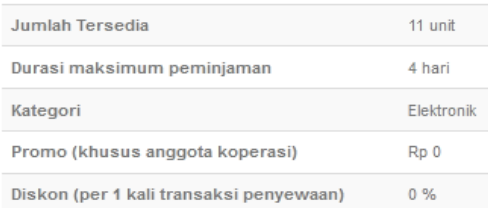

sewa

Gambar 9. Detail barang sewa untuk pengunjung

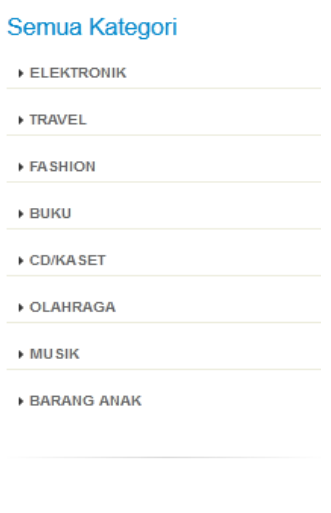


Tombol sewa pada Gambar 9 akan mengarahkan penyewa ke form penyewaan barang seperti yang ditampilkan pada Gambar 10. Form ini berisi jumlah barang yang akan disewa, tanggal mulai dan tanggal akhir sewa, opsi peminjaman (dikirim atau ambil di toko), dan alamat.

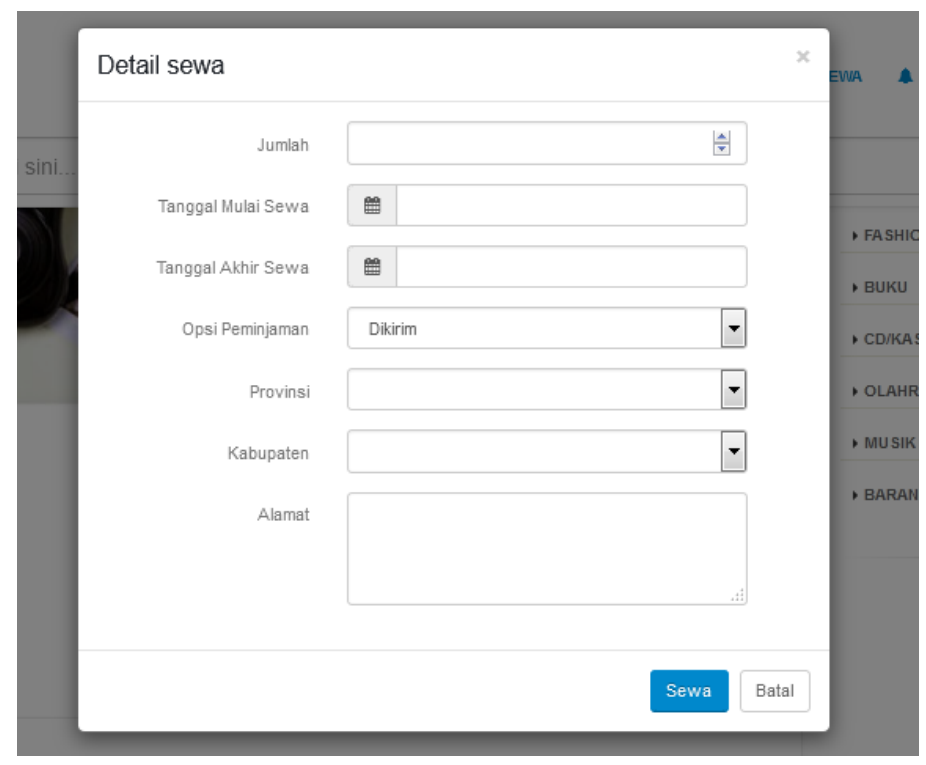

Gambar 10. Form sewa barang untuk penyewa

Alamat toko sewa akan muncul secara otomatis ketika penyewa memilih opsi peminjaman 'ambil di toko', sementara penyewa harus mengisi alamat pengiriman jika memilih opsi peminjaman 'dikirim'. Tombol sewa pada form ini akan mengarahkan penyewa ke halaman keranjang sewa.

\subsection{Pengujian}

Aplikasi marketplace penyewaan untuk koperasi diuji menggunakan black box testing. Metode black box testing yang digunakan adalah equivalence partitioning. Pengujian dibagi berdasarkan aktor yang ada pada aplikasi marketplace penyewaan yaitu super administrator, administrator, penyewa, dan pengunjung. Dua puluh satu kelas uji dibagi berdasarkan tugas masing-masing aktor yang tertera pada usecase diagram (Gambar 2). Bagian super adminisrator diuji oleh pengembang sistem sedangkan bagian administrator, penyewa, dan pengunjung diuji bersama dengan pihak Koperasi Syariah Al-Kautsar. Hasil pengujian menunjukkan bahwa menu, tombol, dan antarmuka pada bagian super administrator, administrator, penyewa, dan pengunjung telah berfungsi sesuai dengan hasil yang diharapkan.

\section{KESIMPULAN}

Berdasarkan penelitian yang telah dilakukan, dapat disimpulkan bahwa aplikasi marketplace penyewaan untuk koperasi berhasil dibangun menggunakan framework Laravel dan telah diuji menggunakan black box testing dengan metode equivalence partitioning. Aplikasi marketplace penyewaan untuk koperasi menggunakan Laravel dapat digunakan oleh lebih dari satu koperasi atau toko sewa, dapat mengelola data barang sewa, mencatat transaksi penyewaan barang, dan membuat akun toko sewa online. Saran untuk pengembangan aplikasi ini adalah penambahan API virtual account pada bank koperasi untuk mempermudah proses pembayaran.

\section{DAFTAR PUSTAKA}

[1] C. F. Sitepu and Hasyim, "Perkembangan Ekonomi Koperasi di Indonesia," Niagawan, vol. 7, no. 2, pp. 59-68, Jul. 2018. 
[2] B. Limbong, Pengusaha Koperasi, Jakarta: Margaretha Pustaka, 2012.

[3] F. M. Wijaya and S. Khairani, "Analisis Sistem Prosedur Penerimaan Kas dari Penyewaan Kendaraan Pada Koperasi Karyawan Utama PT PLN," STIE Multi Data Palembang, 2013.

[4] F. Az Zahra, F. Pradana and E. M. A. Jonemaro, "Pengembangan Aplikasi Portal Penyewaan Barang di Kota Malang Berbasis Web," Jurnal Pengembangan Teknologi Informasi dan Ilmu Komputer, vol. 3, no. 7, pp. 7043-7050, Jul. 2019.

[5] J. J. Weygandt, P. D. Kimmel and D. D. Kieso, Financial Accounting: IFRS Edition, USA: John Wiley \& Sons, 2011.

[6] W. Prodjodikoro, Azas-Azas Hukum Perjanjian, Bandung: Mandar Maju, 2011.

[7] Mansur, "Business To Business (B2B) E-Marketplace Sebagai Media Promosi Produk Usaha Kecil dan Menengah (UKM)," Buletin Bisnis \& Manajemen, vol. 1, no. 1, Feb. 2015.

[8] A. D. Kasman, Framework Laravel 5 Panduan Praktis dan Trik Jitu, Cirebon: CV. ASFA Solution, 2015.

[9] L. Triyono, Sistem Informasi Akademik Kampus Berbasis Web dengan LARAVEL 5, Yogyakarta: Lokomedia, 2016.

[10] V. V. Parkar, P. P. Shinde, S. C. Gadade and P. M. Shinde, "Utilization of Laravel Framework for Development of Web Based Recruitment Tool," IOSR Journal of Computer Engineering (IOSR-JCE), pp. 36-41, 2016.

[11] A. Fatoni and D. Dwi, "Rancang Bangun Sistem Extreme Programming Sebagai Metodologi Pengembangan Sistem," Jurnal PROSISKO, vol. 3, no. 1, pp. 17-20, Mar. 2016.

[12] R. S. Pressman and B. R. Maxim, Software Engineering: A Practitioner's Approach, 8th ed., New York: McGraw-Hill, 2015.

[13] A. Hendini, "Pemodelan UML Sistem Informasi Monitoring Penjualan dan Stok Barang (Studi Kasus: Distro Zhezha Pontianak)," Jurnal Khatulistiwa Informatika, vol. 4, no. 2, pp. 107-116, Dec. 2016.

[14] I. Carolina and A. Supriyatna, "Penerapan Metode Extreme Programming Dalam Perancangan Aplikasi Penghitungan Kuota SKS Mengajar Dosen," Jurnal IKRA-ITH Informatika, vol. 3, no. 1, pp.106-113, Mar. 2019.

[15] R. A. Sukamto and M. Shalahuddin, Modul Pembelajaran Rekayasa Perangkat Lunak (Terstruktur dan Berorientasi Objek), Bandung: Modula, 2011. 